\title{
VERBAL HUMOUR CREATED BY NON-OBSERVANCE OF COOPERATIVE PRINCIPLE IN MIRANDA
}

\author{
Bara Yamalita Oksinia, I Gusti Agung Sri Rwa Jayantini, I Komang Sulatra \\ Universitas Mahasaraswati Denpasar, Bali, Indonesia \\ E-mail: agung_srijayantini@unmas.ac.id
}

Received: 2021-02-20

Accepted: 2021-04-25

\begin{abstract}
Humour is one of essential aspects to communicate with other people comfortably. Most of verbal humours, especially implicit humours generate because people break Grice's four conversational maxims. Concerning this phenomenon, this research aims to find out types of non-observance of cooperative principle found in verbal humour, which uttered by the characters in British Situational Comedy Miranda. Qualitative method was adapted to analyze the data, which was conducted through identifying, classifying, interpreting the data. Humorous utterances from nine episodes of Miranda were the primary sources of data. In collecting the data, the researchers observed the whole episodes and the scripts, checked the suitability, took a note, and classified it into tables. The study concludes that there are four types of non-observance of cooperative principle, namely violating, flouting, infringing, and opting out a maxim. The result reveals that there are 80 humorous utterances, which do not obey the maxim. There are 66 utterances $(82,5 \%)$ of flouting maxim, 10 utterances $(12,5 \%)$ violation maxim, 3 utterances $(3,75 \%)$ of infringing maxim, and 1 utterance $(1,25 \%)$ of opting out maxim which are found in the sitcom.
\end{abstract}

Keywords: cooperative principle, non-observance of cooperative principle, situational comedy, verbal humour

\section{Introduction}

Conversation is the most significant part in communication. People interact to each other to exchange information and express their ideas. Conversation is an activity between two or more participants use verbal and non-verbal signs to communicate (Pashler \& Brennan, 2013). The participants utter the required information related to the topic of conversation. Thus, people must adhere a set of rules of conversation to accomplish mutual goals and avoid misunderstandings (Rafika et al., 2020). The basic rules of conversation are termed as the cooperative principle. Grice (1989) differentiates the cooperative principle into four conversational maxims. Each individual are assumed to cooperate in an attempt to be informative, truthful, relevant, and comprehensible to other individual.

Nevertheless, people occasionally do not abide by the maxims when they deliver their speech in particular contexts of our life, including humour by disregarding the validity, amount, appropriateness, and the way information is given during conversation (Awwad et al., 2019). People organize their speech to create particular meanings which are not understable on every occasion without knowing the context to win the support of the public to reach their goals (Ayasreh \& Razali, 2018; Massanga \& Msuya, 2017). They generate an 
implicature which actually do not contain the real meaning whether it occurs intentionally or unintentionally (Khakipour, 2017; Lestari, 2019). The speakers expect the hearers are being cooperative in the talk exchange. When their utterances appear to diverge from the maxims, the hearers initiate to find out the hidden meaning of the utterances and make inferences based on the cooperative principle. The hearer should know the speaker's background, the time of utterance, and the meaning on certain situation in utterances to comprehend what the speaker said thoroughly (Grice, 1989: 25). Grice defines these occurences as the nonobservance of cooperative principle. It is a condition when people do not imply the maxims in several ways, such as flouting, violating, infringing, opting-out, and suspending a maxim. People break a maxim as the result of incoherent speech or their decision to deceive others by providing false information (Thomas, 2014).

Non-observance of cooperative principle is frequently used to produce verbal humour in daily conversation (Kehinde, 2016). People may have utter explicit verbal humour that is not required a specific knowledge to understand by the hearer. However, the implicit verbal humour happens on the most occasions. Humour involves creating obscure literal meaning which is considered to be funny (Hoicka, 2014). It causes conversational implicatures which means the hearer should realise any certain context to draw the inference. For instance, British people have a tendency to express their implicit verbal humour in the form of irony, sarcastic and self-deprecation expressions with deadpan tone (Easthope, 2004). However, people from other nations may think the humour in different ways (Jiang et al., 2019). For some people, especially non-native speakers, British sense of humour is regarded as impolite and not amusing in the slightest, due to the culture differences, unfamiliar terms, and the use of languages.

This research is conducted to analyse types of non-observance of cooperative principle using Grice's theory in verbal humour. The Grice's theory enables to identify how verbal humour was formed by not obeying maxims and its implied meaning. The researchers examined humorous utterances uttered by the characters in a British television situational comedy entitled Miranda, which was aired on BBC two on $9^{\text {th }}$ November 2009 until $1^{\text {st }}$ January 2015. This series won a Royal Television Society award and nominated in BAFTA TV award several times and becomes one of the popular British situational comedies.

\section{Literature Review}

Several studies are found related to non-observance of cooperative principle. Kuang and Zhao (2017) observed types of non-observance of Grice's maxims in Chinese situational comedy Home with Kids season four. Saradifa (2020) focused on analyzing types of nonobservance maxims in the script of drama series "The Grapevine: Gossip at Work, What Should You Do as A Leader?". The two studies discovered similar results that the characters in the show are mostly used flouting maxim as a way to not observing the maxim. The findings of these studies matched with Fadillah and Imperiani (2020) as the writers revealed flouting maxim, specifically flouting maxim of quantity, is the most prominent type of non observance of maxims used by the passengers, either Indonesians or foreigners, in conversations between passengers and custom officers at Indonesian airport. From five videos in the 86 and Custom Protection NET Youtube Channel, the passengers intentionally break the maxim by adding unrequired information of their new item from overseas to the custom officers. It showed that they intended to convince the officers and tried to avoid paying the tax.

Of five categories of non-observance of cooperative principle, Puspasari and Ariyanti 
(2019) chose to focus in identifying the flouting maxim and type of joke techniques found in both Indonesian and American stand-up comedy. The writers found that Indonesian comic, Abdur Arsyad mainly flouted maxim of quality, while the American comic, Kevin Hart, flouted maxim of quantity. In addition, both stand-up comics constantly used ridicule as a joke technique to create humour.

Meanwhile, Qassemi et al. (2018) examined violation of maxim and which maxims that had been violated from 120 news reports in Tehran Times newspaper. The news reports consisted of five news categories, such as sport, political, economic, social, and cultural news. The result of the research showed that violation maxim of quality mostly found in five categories of the news.

The previous studies and the current study analysed the non-observance of cooperative principle by using Grice's (1989) theory. However, this research is dissimilar with the previous studies as the writers used humorous dialogues in British televison situational comedy Miranda as the source of data. The researchers analysed not only flouting or violating a maxim, but also infringing, opting out, and suspending maxim in verbal humour.

\subsection{Cooperative Principle}

\section{a. Maxim of Quantity}

Grice (1989: 26) states that the speaker can not make his contribution more or less informative than is needed to obey this maxim. This type of maxim expects the speakers transmit accurate information that the hearers needed, without more or less information. The speaker should estimate how much information the hearer needs by saying "To cut a long story short, she didn't get home till two." (Cutting, 2002: 34)

\section{b. Maxim of Quality}

As a result of using this maxim, the speakers provide truthful and valid information to the hearers. People should not speak false or lack of evidences utterances to reach mutual goals in conversation (Grice, 1989: 27). Grice explains that "If I need sugar as an ingredient in the cake you are assisting me to make, I do not expect you to hand me salt" to illustrate the use of maxim of quality.

\section{c. Maxim of Relation}

When the speakers use this maxim, they suppose to say relevant things that has been said by other speaker (Cutting, 2002: 35). Grice uses the following analogy of maxim of relation: "If I am mixing ingredients for a cake, I do not expect to be handed a good book or even an oven cloth". It means that the speaker should be relevant during conversation with the other person.

\section{d. Maxim of Manner}

In using the last maxim, people are expected to say things briefly and orderly. People should not talk in ambiguous way to avoid misunderstanding. He described maxim of manner is about how people utter the messages or information to be interpreted by the hearers (Grice, 1989: 28).

\subsection{Non-Observance of Cooperative Principle}

\section{a. Flouting Maxim}


Flouting maxim occurs when the speakers intentionally fail to observe a maxim and generates indirect meaning without any intention to mislead the hearers. It prompts the hearers to infer the implied meaning instead of the literal meaning of their utterances. The listener's intrepetations are based on the assumption of cooperation which means if people exceedingly deviate the maxim, then their utterances are still considered as cooperative (Levinson, 1983: 109).

\section{b. Violating Maxim}

The speakers violate the maxim if they have the intention to mislead and deceive the hearer on purpose by not following maxim in their utterances. The speakers violate the maxim with the purpose that the hearer do not know the truth of their utterances and assume the literal meaning of what it is said (Al-Zubeiry, 2020). They deliberately delivers inadequate information because they do not want the hearer has the knowledge of whole information.

\section{c. Infringing Maxim}

When the speaker do not comply with maxim unintendedly without implying something, it is defined as infringing a maxim (Thomas, 2014). The cause of this condition is usually because of the speaker's imperfect language performances, such as agitation, excitement, or drunkenness. The limited knowledge of such language of foreigners or children also become the cause of people infringe the maxim.

\section{d. Opting-out Maxim}

Grice (1989: 30) states that the speaker chooses to opt out of a maxim because he's unwilling to cooperate within the way maxim requires. He may say "I can not say more" or "My lips are sealed." The speakers intend to avoid causing an implicature or appearing uncooperative for legal or ethical reasons (Thomas, 2014).

\section{e. Suspending Maxim}

Suspending maxim occurs when the speakers do not comply with one or more maxims in certain occasion in which the maxim does not always expected to obey by the participants (Martinich \& Stroll, 2007). This type of non-observance happens due to cultural differences or events. During those circumstances, people do not expect others to fulfill the maxim. Therefore, their utterances do not contain implied meaning even if the speakers break the maxim.

\section{Research Method}

A study of how people disclose the meaning of particular phenomenons is qualitative research (Merriam, 2009). This study applied qualitative method and descriptive technique to analyse types of non-observance of cooperative principle in verbal humour in British television situational comedy Miranda. The sources of data are the humorous utterances which contained of flouting, violating, infringing, opting out, and suspending a maxim from 9 most viewed episodes of 20 episodes in Miranda, which entitled as follows: "Date", "Teacher", "Holiday, "The new me", "Before I die", "Let's do it", "A new low", "It was panning", and "Je regret nothing". In collecting the data, the researchers applied documentation method. The researchers collected the data by using these following steps: 
1. Downloading and watching 9 episodes of the situational comedy Miranda to comprehend the story of the show by watching the selected episodes of Miranda.

2. Retrieving the transcript of 9 episodes of Miranda from https://subsaga.com/bbc/comedy/miranda/.

3. Checking the suitability between the sitcom and the transcripts to discover the context of the utterances.

4. Highlighting the humorous utterances which contained non-observance of cooperative principle.

In qualitative method, the data analysis involves several steps, namely organize the raw data, analyse the data in detail with a coding process, interpret the data based on the context and theories, and make a conclusion (Creswell, 2009). In analysing the data, the researchers applied four steps as follows.

1. The researchers identified humorous utterances based on Grice's (1989) theory of nonobservance of cooperative principle.

2. The researchers classified the data into different categories based on the theory.

3. The researchers described the analysis of the data in each type of the non-observance of cooperative.

4. The researchers concluded the findings of the research.

\section{Results and Discussion}

The results of the non-observance of cooperative principle in creating verbal humour found in Miranda are presented in the form of a table. The writers discovered 80 humorous utterances from Miranda situational comedy. The findings are classified into 4 categories as shown in Table 4.1.

Table 4.1 Occurences of Non-Observance of Cooperative Principle in Miranda

\begin{tabular}{|c|c|c|c|c|c|}
\hline \multirow{2}{*}{ No } & \multicolumn{5}{|c|}{ Non-Observance of Cooperative Principle } \\
\cline { 2 - 6 } & Types of Maxim & Flouting & Violating & Infringing & Opting-out \\
\hline 1. & Maxim of Quantity & 29 & 1 & - & - \\
\hline 2. & Maxim of Quality & 12 & 9 & 2 & 1 \\
\hline 3. & Maxim of Relation & 10 & - & - & - \\
\hline 4 & Maxim of Manner & 13 & - & 1 & - \\
\hline 5. & $\begin{array}{c}\text { Maxim of Quantity } \\
\text { and Relation }\end{array}$ & 1 & - & - & - \\
\hline 6 & $\begin{array}{c}\text { Maxim of Quantity } \\
\text { and Manner }\end{array}$ & 1 & - & - & - \\
\hline \multicolumn{7}{c}{ Frequency } & 66 & 10 & 3 & $1,25 \%$ \\
\hline
\end{tabular}

The study revealed that there are 4 types of non-observance of cooperative principle found in 9 episodes of Miranda, namely flouting, violating, infringing, and opting out a maxim. From the total 80 data of verbal humour, the most dominant type of non-observance is flouting maxim which occurs 66 times or $82.5 \%$, followed by violating maxim with its percentage $12.5 \%$ or 10 occurences and infringing maxim with percentage $3.75 \%$. Suspending maxim is the only type that is not found in the show. The further explanation of 
Verbal Humour Created by Non-Observance of Cooperative Principle in Miranda, Bara Yamalita Oksinia, I Gusti Agung Sri Rwa Jayantini, I Komang Sulatra

humorous utterances containing non-observance of cooperative principle found in Miranda are as follows.

\section{Data 1}

(Episode 13, 19:49-20:02)

Dick Twist : "Well, have you considered getting a partner?"

Penny : "Oh, we have tried and tried, Dick, if you pardon the vernacular. She couldn't attract a partner if you shoved a giant magnet down her blouse and sat her next to a man made of iron filings!"

In the example above, the dialogue occured between Miranda, her mother Penny, and the business manager, Dick Twist in Miranda's shop. They discussed future business plans for Miranda's joke shop that faced a heightened risk of bankruptcy. When Twist offered his solution for getting a business partner for Miranda, Penny interrupted him and expressed her frustration about Miranda of being single. She could just say the first sentence to fulfill the maxim, which showed that Miranda and Penny have tried getting a partner. However, what Penny meant referring to partner was not business partner, but a life partner or a husband. As shown in the bolded utterance, Penny gave extended explanation of Miranda's personal problem about how she believed that Miranda could not attract a man even if she had a magnet inside her blouse and sat next to a man made of iron fillings. Penny provided too much unrequired information to Twist, which caused humorous effect as she blatantly exposed her daughter's secret to a stranger. Thus, she flouted maxim of quantity as the result of not observing maxim and offered more information that is not required.

\section{Data 2}

(Episode 8, 04:00-04:10)

Gary : "What's going on?"

Miranda : "Someone's dead, don't know who, funeral in two hours. I can't go, can I? Not when I don't know who's in the box. It'll be like Deal or No Deal, but with people."

This example shows that Miranda's utterance flouted maxim of quantity when she expressed her thoughts too much to Gary. The dialogue occurred when Miranda got a voice message from her aunt about her relative's death. However, she accidentally deleted the message as her aunt mentioned her relative's name. As Miranda panicked and paced around her shop, Gary confused and asked her what happened. She explained the situation and answered Gary's question. Nonetheless, she blurted her worries whether she went to the funeral or not as she did not know who died. She continued her endless rambling by comparing her situation like the show "Deal or No Deal". It is a dramatic game television show where the participants play a game of odds and chance by choosing locked briefcases of cash. Her rambling created an amusing situation for the audiences as soon as she made a reference of the game show. She provided unnecessary information to Gary who did not need that information, thus Miranda's absurd utterances flouted maxim of quantity.

\section{Data 3}

(Episode 4, 11:12-11:19)

Room boy : "Fridge, bathroom, bed."

Miranda : "Oh, we've only just met!" 
In this data, Miranda's utterance displays the example of flouting maxim of relation because there is no relevance to the previous utterance. This conversation occurred at the Hamilton Lodge where she stayed to spend her holiday. She pretended to have a vacation in Thailand to her friends while she stayed at the nearby hotel because she was not brave enough to go abroad. The room boy did his duty and showed her the room. Then, Miranda shamelessly blurted that they had only just met which was not relevant with his statement. Her utterance generated an implicature right after the room boy said the word "bed". Miranda implied that he flirted with her in order to sleep with her intimately. She uttered irrelevant things and not related to the topic. Hence, she flouted maxim of relation in her speech. She also made a hilarious situation for the audiences and created humour.

\section{Data 4}

(Episode 1, 12:21-12:31)

Gary : "Look, I just popped in to ask, you're not with anybody, or married or anything at the moment?"

Miranda : :Yep, yep, of course, yeah."

Gary : "Oh, really? Kids?"

Miranda : "Yeah got two."

The conversation above is clearly the example of violating maxim of quality because Miranda deliberately failed to comply with maxim of quality by uttering untrue words with intention to deceive Gary. The dialogue occurred when Gary and Miranda reunited after they had not met for years. Gary came to Miranda's shop next to his restaurant to ask if she was single or already in relationship. Miranda actually was smitten with him, but she chose to lie to him by admitting that she was indeed with someone. Gary believed her and questioned her further whether she already had kids. Miranda chose to mislead him again by saying she got two kids. She violated maxim of quality with a purpose of mislead Gary, because she was embarrassed and did not want him to know her being single. Miranda's obvious lies made the situation amusing because the audiences clearly knew she was single but she admitted that she married with two kids.

\section{Data 5}

(Episode 7, 21:52-22:07)

\section{Danny : "What was that?" \\ Miranda : “M-m-m-m-me, I'm so excited. M-m-m-m-m! Shall we go? W-w-w-w-wait for me-e-e-e!"}

From the example above, Miranda infringed the maxim of quality because she felt anxious until she could not speak clearly in answering Danny. The dialogue happened when Danny showed up at Miranda's flat to have a dinner date. Meanwhile, at that time, there was a misunderstanding between Miranda and Stevie, her bestfriend. Stevie brought a goat to Miranda's room to help Miranda scared her mother away. Stevie misunderstood Miranda's word of 'ghost' into 'goat'. As soon as Danny pressed the bell, Miranda hastily tried to hide the goat. However, when Miranda opened the door, the goat bleated all of sudden. Danny asked about it, while Miranda became nervous and imitated the goat's bleats in her utterance to cover it up. Here, she infringed a maxim as she uttered in incoherent 
Verbal Humour Created by Non-Observance of Cooperative Principle in Miranda, Bara Yamalita Oksinia, I Gusti Agung Sri Rwa Jayantini, I Komang Sulatra

speech without any intention to imply something because of her nervousness. She just did not want him to know that there was a goat in her room. Her utterance also created a humorous effect because she did ridiculous things by mimicking the goat's bleats.

\section{Data 6}

(Episode 9, 13:35-13:39)

Stevie : "Are you sure nothing happened?"

Miranda : : "My lips are sealed, my face is a mask."

In this dialogue, it is showed that there is a phenomenon of opting out of a maxim in Miranda's utterance because she was unwilling to answer Stevie's question. The dialogue took place at Miranda's shop where Stevie and Miranda talked about Miranda's date with Gary the other night. The truth was Gary actually spent his time for a while at Miranda's room after dinner which involved romantic kisses between them. When Stevie asked about her date, instead of telling her about what happened, she decided not to tell her by saying "My lips are sealed", since Miranda still couldn't believe that she was getting kissed by Gary. Therefore, her utterances are classified as opting out a maxim and created a humorous effect for the audiences because of her exaggerated speeches.

\section{Conclusion}

This study reveals that there are differences of the findings with the prior researches which mostly found and analysed flouting and violating maxim. As stated in the findings of the study, it is deduced that there are four types of non-observance of cooperative principle out of five types in verbal humour found in the situational comedy Miranda, namely flouting, violating, infringing, and opting out a maxim. From 80 data of humorous utterances, the only type of non-observance that is not detected is suspending a maxim. The most frequent type of non-observance of cooperative principle is flouting maxim, which means the characters mostly did not observe the maxims to generate indirect meaning to the audiences.

In flouting maxim, most characters flouted maxim of quantity. It means the characters provided unnecessary information and creates humorous situations. The second most frequent strategy is violation of maxim. The speaker failed to obey a maxim to mislead the other person intentionally. It means they lied and uttered untrue words to the hearer on purpose to change the topic. The researchers also discovered that the characters are also infringing a maxim and opting out a maxim. In infringing maxim, the speakers delivered an unclear speech because of nervousness and excitement with no intention to mislead or imply something. In opting out a maxim, the characters were unwilling to obey a maxim without implied meaning by not telling anything to the hearer.

Based on the result and discussions, the writers found fewer examples of opting-out and suspending maxim. Due to that reason, it is suggested that the future researchers with similar topic to provide more data of those categories. The researchers also offer a suggestion for other authors to conduct researches which have not been explored, for instance suspending maxim analysis in certain cultural events.

\section{References}

Al-Zubeiry, H. Y. (2020). Violation of Grice's Maxims and Humorous Implicatures In the Arabic Comedy Madraset Al-Mushaghbeen. Journal of Language and Linguistic Studies, 16(2), 1043-1057. https://doi.org/10.17263/jlls.759363 
Ayasreh, A., \& Razali, R. (2018). The Flouting of Grice's Conversational Maxim: Examples from Bashar Al-Assad's Interview during the Arab Spring. IOSR Journal Of Humanities And Social Science (IOSR-JHSS), 23(5), 43-47.

Awwad, A. S., Ayasreh, A. M., Ayasrah, N. M., \& Al-Sabti, N. (2019). Interpretations of the Gricean Conversational Maxims Violations. International Journal of Applied Engineering Research, 14(22), 4100-4104.

Creswell, J. W. (2009). Research Design: Qualitative, Quantitative, and Mixed Methods Approaches The Selection of a Research Design. Thousand Oaks : SAGE Publications.

Cutting, J. (2005). Pragmatics and Discourse. London: Routledge.

Easthope, A. (2004). Englishness and National Culture. London: Routledge.

Fadillah, M., \& Imperiani, E. D. A. (2020). An Analysis of Non-Observance Maxims in Customs Protection. Proceedings of the Twelfth Conference on Applied Linguistics 2019 (pp.130-133). Bandung: Language Center of Universitas Pendidikan Indonesia. https://doi.org/10.2991/assehr.k.200406.026

Grice, H. P. (1989). Studies in the Way of Words. Harvard University Press.

Hoicka, E. (2014). The Pragmatic Development of Humor. In Daniel Matthews. Pragmatic Development in First Language Acquisition (pp. 219-237). Amsterdam: John Benjamins Publishing Company.

Jiang, T., Li, H., \& Hou, Y. (2019). Cultural Differences In Humor Perception, Usage, and Implications. Frontiers in Psychology. https://doi.org/10.3389/fpsyg.2019.00123

Kehinde, O. F. (2016). A Night of a Thousand Laughs: A Pragmatic Study of Humour in Nigeria. International Journal of Scientific and Research Publications, 6(6), 433-436.

Khakipour, S. (2017). Comedy, Context and Unsaid Meaning: A Case Study in Conversational Implicature. Journal of Language and Translation, 7(2), 63-71.

Kuang, C. H., \& Xue, Z. (2017). Grice's Maxims In Humour: The Case of "Home with Kids." English Review: Journal of English Education, 6(1), 49-58.

Lestari, N. G. (2019). An Analysis of Flouting Maxims in Conversation Speaking of the Main Character in the Movie of Home Alone 2 "Lost in New York" by John Hughes. Jurnal JOEPALLT (Journal of English Pedagogy, Linguistics, Literature, and Teaching), 7(1). https://doi.org/10.35194/jj.v7i1.537

Levinson, S. C. (1983). Pragmatics. New York: Cambridge University Press.

Martinich, A. ., \& Stroll, A. (2007). Much Ado about Nonexistence: Fiction and Reference. Lanham: Rowan \& Littlefield Publishers.

Massanga, M., \& Msuya, E. A. (2017). The Observance of Gricean Conversational Maxims by Tanzanian Politicians in T.V. Hosted Interviews. English Literature and Language Review, 3(9), 82-90.

Merriam, S. B. (2009). Qualitative Research: A Guide to Design and Implementation. San Fransisco: Jossey-Bass.

Pashler, H., \& Brennan, S. E. (2013). Conversation and Dialogue. Encyclopedia of the Mind. https://doi.org/10.4135/9781452257044.n75

Puspasari, M. A., \& Ariyanti, L. (2019). Flouting Maxims In Creating Humor: A comparison Study Between Indonesian and American Stand Up Comedy. Prosodi, 13(2), 75-88. https://doi.org/10.21107/prosodi.v13i2.6084

Qassemi, M., Ziabari, R. S., \& Kheirabadi, I. R. (2013). Grice's Cooperative Principles in News Reports of Tehran Times-A Descriptive-Analytical Study. International Journal of English Language \& Translation Studies, 6(1), 66-74.

Rafika, R., Yulliasri, I., Warsono, W. (2020). Flouting of Grice's Maxim in the Humorous 
Verbal Humour Created by Non-Observance of Cooperative Principle in Miranda, Bara Yamalita Oksinia, I Gusti Agung Sri Rwa Jayantini, I Komang Sulatra

Utterances in American Situation Comedy 2 Broke Girls. English Education Journal, 10(4), 474-479. https://doi.org/10.15294/eej.v10i4.39465

Saradifa, A. S. (2020). Non-Observance of Grice's Maxims Found in "The Grapevine: Gossip At Work, What Should You Do As A Leader?" Drama Series Script. JELLE: Journal Of English Literature, Linguistics, and Education, 1(1), 1-8.

Thomas, J. A. (2014). Meaning in Interaction : An Introduction to Pragmatics. Abingdon: Routledge. 